\title{
Evaluation of quality of life in adults with chronic health conditions: the role of depressive symptoms
}

\section{Avaliação de qualidade de vida em adultos com e sem doenças crônicas: o papel dos sintomas depressivos}

\author{
Neusa Sica da Rocha, ${ }^{1}$ Marcelo P. Fleck ${ }^{1}$ \\ ${ }^{1}$ Department of Psychiatry and Legal Medicine, Universidade Federal do Rio Grande do Sul (UFRGS), Porto Alegre, RS, Brazil \\ This paper was awarded the "Prêmio Paulo Guedes" by the "Associação de Psiquiatria do RS" and the Best Poster Award by the "Lista \\ Brasileira de Qualidade de Vida".
}

\begin{abstract}
Objective: The negative impact of depressive symptoms on quality of life has been the focus of increasing attention, yet this relation remains unstudied in samples from developing countries. The objective of this study was to determine whether the occurrence of depressive symptoms is associated with impaired quality of life and whether this association remains significant after adjustment for some variables. Method: A convenience sample was selected and the measures used were the WHOQOL-100, to assess quality of life, the Beck Depression Inventory, to screen for depressive symptoms, and the Economic Classification Criterion - Brazil, to evaluate socioeconomic status. Results: One hundred nineteen healthy adults (community) and 122 adult patients (tertiary hospital) from Brazil were assessed. Depressive symptoms were negatively correlated with all the domains of quality of life, even after statistical control for age, socioeconomic status, and presence of chronic health conditions. Socioeconomic status was positively correlated with the social relationships and environmental domains of quality of life. Conclusion: Our findings indicate that depressive symptoms and socioeconomic status are important elements affecting the relationship between chronic health conditions and quality of life in Brazil.
\end{abstract}

Descriptors: Quality of life; Chronic disease; Depression; World Health Organization; Social conditions

\begin{abstract}
Resumo
Objetivo: $O$ impacto negativo dos sintomas depressivos na qualidade de vida tem sido foco de crescente atenção, mas esta relação permanece pouco estudada em paises em desenvolvimento. O objetivo deste trabalho é verificar se a ocorrência de sintomas depressivos está associada a pior qualidade de vida e se esta associação permanece significativa após ajuste para algumas variáveis. Método: Uma amostra de conveniência foi selecionada e as medidas utilizadas foram o WHOQOL-100 para qualidade de vida, o Inventário de Beck para depressão para sintomas depressivos e o Critério de Classificação Econômica-Brasil para nivel socioeconômico. Resultados: Cento e dezenove adultos saudáveis (comunidade) e 122 pacientes adultos (hospital terciário) do Brasil foram avaliados. Os sintomas depressivos parecem estar negativamente correlacionados com todos os dominios da qualidade de vida, mesmo após controle estatístico para idade, nivel socioeconômico e a presença de uma doença crônica. O nivel socioeconômico aparece positivamente correlacionado com os dominios social e ambiental da qualidade de vida. Conclusão: Nossos achados indicam que os sintomas depressivos e o nivel socioeconômico podem ser fatores intervenientes relevantes entre a presença de uma doença crônica e sua associação com qualidade de vida no Brasil.
\end{abstract}

Descritores: Qualidade de vida; Doença crônica; Depressão; Organização Mundial da Saúde; Condições sociais

\section{Introduction}

The presence of depressive symptoms in patients with clinical diseases has been extensively described in the literature. There are reports of higher prevalence rates of depression in these patients as compared with the general population, ranging between $18 \%$ and $83 \%$, depending on the research methodology and medical condition under study. ${ }^{1-5}$ The presence of one or more chronic medical conditions increases the prevalence of current and lifetime depression in between $5.8 \%$ and $9.4 \%$, and $8.9 \%$ and $12.9 \%$, respectively. ${ }^{5}$

Depressive disorders have been implicated in the worsening of quality of life (QOL) and physical health, impaired ability to perform daily life activities ${ }^{6-9}$ poor treatment compliance, and higher morbidity and mortality rates. ${ }^{10-18}$
Submitted: April 6, 2009

Accepted: March 10, 2010
Correspondence

Neusa Sica da Rocha

Avenida Iguaçu, 119/201

90470-430, Porto Alegre, RS, Brazil

Phone: (+55 51) 3338-0496 Fax: (+55 51) 3330-8965

E-mail: neusa-rocha@via-rs.net 
Depressed individuals present long-lasting problems in multiple domains of functioning and well-being, which may be equal to or even greater than those caused by other chronic medical conditions. ${ }^{19,20}$ There is evidence that depression is associated with impaired social functioning, ${ }^{7}$ and that improvement in depression is related to improved work capacity.

Some researchers have suggested that even in the absence of a diagnosis of depressive disorder, the occurrence of depressive symptoms is related to impairment in the QOL of individuals suffering from chronic health conditions. ${ }^{6,7,10,21-24}$ Accordingly, it seems correct to assume that subsyndromal depression may affect the QOL in Brazilian primary care patients. ${ }^{25}$ The impact of depressive symptoms insufficient to characterize a diagnosis of depressive disorder on healthy individuals remains unstudied.

Estimates of the prevalence of depression in Brazil show considerable variation between the different regions of the country, ranging from less than 3\% in São Paulo and Brasília to 10\% in Porto Alegre. ${ }^{26} \mathrm{~A}$ Brazilian study found that depressive symptoms can predict mortality in medical inpatients ${ }^{16}$ and there is also evidence suggesting that the frequency of depressive symptoms is associated with poor social conditions. ${ }^{27-29}$

The objectives of the present study were 1) to evaluate the association between depressive symptoms and QOL as assessed by the WHOQOL-100 in healthy and clinically ill patients; and 2) to evaluate whether the association between QOL and depressive symptoms persists after statistical adjustments for age, presence of chronic health conditions, and socioeconomic status. We hypothesized that depressive symptoms would be significantly associated with impaired QOL in adults regardless of the presence of chronic health conditions.

\section{Method}

Participants were recruited from the wards and the outpatient clinic of a university hospital, as well as from the community of the city of Porto Alegre, Brazil, during a three-month period. Porto Alegre is the capital of the southern State of Rio Grande do Sul. The State's economy is largely based on agribusiness and its capital has a population of around two million people, mostly descendants of European immigrants.

A convenience sample was selected, both in the case of patients and healthy individuals. The snowball technique was used to select the group of healthy individuals (each selected individual indicated another participant). ${ }^{30}$ This technique is usually implemented when searching for individuals who are not directly accessible to researchers. ${ }^{31}$

\section{Inclusion criteria for the patient group}

Adult ( $\geq 18$ years of age) inpatients from the different clinical and surgical specialties wards and from the outpatient clinic of the Hospital de Clínicas de Porto Alegre who agreed to participate in the study.

\section{Inclusion criteria for the healthy group}

Adults ( $\geq 18$ years of age) living in the geographical area close to the hospital without any clinically detectable health conditions. Individuals providing affirmative answers to any of the questions below were excluded from the sample:

1) Do you have any chronic diseases?

2) Are you currently using any regular medication?

3) Have you seen a physician or health professional during the last month (except for preventive care, such as a gynecological check-up)?

\section{Measures}

WHOQOL-100: designed by the World Health Organization to evaluate QOL, this questionnaire is a cross-cultural self-report instrument comprising six domains: physical, psychological, level of independence, social relationships, environment, and spirituality. ${ }^{32,33}$

Beck Depression Inventory (BDI): a self-report instrument that screens for depressive symptoms and that has been validated and translated into Portuguese. . $^{3,35}$

Economic Classification Criterion - Brazil: this instrument evaluates socioeconomic status (SES) by considering consumption habits and level of education. ${ }^{36}$

The Ethics Research Committee of the Hospital de Clínicas de Porto Alegre has reviewed and approved the research protocol (98-253).

\section{Statistical analysis}

The following analyses were performed: Student's t-test to compare means; Pearson's Chi-square with Yates' correction to compare the proportions of the categorical variables, when necessary; Multiple Linear Regression to adjust for the differences found between patients and healthy individuals in regard to the dependent (WHOQOL-100 domains) and independent (age, SES, BDI score, and presence of a chronic health condition) variables. ${ }^{37}$

The level of significance was set at 5\% for all tests, including Multiple Linear Regression. The statistical software used was SPSS 14.0.

\section{Results}

The total sample comprised 241 adults. The general characteristics of the sample are shown in Table 1 . The most frequently reported health problems were hypertension (18\%), heart diseases (15.6\%), neoplasm (13.1\%), diabetes (13.1\%), emphysema/asthma/bronchitis (11.5\%), autoimmune diseases (8.2\%), and kidney diseases (8.2\%).

Depressive symptoms were more common in the patient group than in healthy individuals, as assessed using the BDI mean scores.

Patients and healthy individuals were divided according to the presence of BDI scores suggestive of depressive disorder ${ }^{35}(\geq 9)$. A statistically significant higher percentage $(47.5 \%)$ of depressive syndromes was found in patients as compared with healthy individuals (16\%, $\left.\mathrm{x}^{2}=27,62 ; \mathrm{DF}=1 ; \mathrm{p}=0.0001\right)$. This difference resulted in an odds ratio of $4.8(95 \% \mathrm{CI}: 2.6 ; 8.4)$ for the patient group 
Table 1 - Subjects general characteristics

\begin{tabular}{|c|c|c|c|c|}
\hline & $\begin{array}{l}\text { Chronic health conditions } \\
\qquad N=122\end{array}$ & $\begin{array}{l}\text { Healthy } \\
\mathrm{N}=119\end{array}$ & & p-value \\
\hline Sex & & & $X^{2}=0.32 ; \mathrm{DF}=1$ & $0.66^{*}$ \\
\hline Male & $66(54.1 \%)$ & $60(50.4 \%)$ & & \\
\hline Female & $56(45.9 \%)$ & $59(49.6 \%)$ & & \\
\hline Age [mean (SD)] & $45.15(15.54)$ & $39.38(15.3)$ & $\mathrm{t}=2.91 ; \mathrm{DF}=239$ & $0.004^{\star \star}$ \\
\hline Years of study [mean (SD)] & $8.93(3.99)$ & $13.13(6.58)$ & $t=-5.59 ; D F=156.9$ & $0.0001^{* *}$ \\
\hline Education & & & $X^{2}=63.18 ; \mathrm{DF}=7$ & $0.0001^{* * *}$ \\
\hline Elementary school & $71(58.2 \%)$ & $22(18.5 \%)$ & & \\
\hline High school & $32(26.2 \%)$ & $30(25.2 \%)$ & & \\
\hline Graduation & $14(11.5 \%)$ & $60(50.4 \%)$ & & \\
\hline Post-graduation & $5(4.1 \%)$ & $7(5.9 \%)$ & & \\
\hline Religion & & & $X^{2}=1.31 ; \mathrm{DF}=4$ & $0.86^{* * *}$ \\
\hline Catholic & $89(73.0 \%)$ & $85(71.3 \%)$ & & \\
\hline Evangelical & $17(13.9 \%)$ & $16(13.4 \%)$ & & \\
\hline Spiritualist & $6(4.9 \%)$ & $5(4.2 \%)$ & & \\
\hline Afro-Brazilian & $4(3.3 \%)$ & $3(2.5 \%)$ & & \\
\hline Atheist & $6(4.9 \%)$ & $10(8.4 \%)$ & & \\
\hline Marital status & & & $X^{2}=13.62 ; \mathrm{DF}=5$ & $0.02^{* * *}$ \\
\hline Single & $29(23.8 \%)$ & $46(38.7 \%)$ & & \\
\hline Married & $57(46.7 \%)$ & $53(44.5 \%)$ & & \\
\hline Living with a partner & $15(12.3 \%)$ & $4(3.4 \%)$ & & \\
\hline Separated & $7(5.7 \%)$ & $4(3.4 \%)$ & & \\
\hline Divorced & $3(2.5 \%)$ & $6(5 \%)$ & & \\
\hline Widowed & $11(9 \%)$ & $6(5 \%)$ & & \\
\hline $\begin{array}{l}\text { Socioeconomic level (social } \\
\text { class) }\end{array}$ & & & $X^{2}=0.27 ; \mathrm{DF}=4$ & $0.0001^{* * *}$ \\
\hline$A^{\dagger}$ & $10(8.2 \%)$ & $47(39.5 \%)$ & & \\
\hline B & $38(31.1 \%)$ & $41(34.5 \%)$ & & \\
\hline C & $62(50.8 \%)$ & $28(23.5 \%)$ & & \\
\hline D & $11(9.0 \%)$ & $3(2.5 \%)$ & & \\
\hline E & $1(0.8 \%)$ & 0 & & \\
\hline Total BDI score [mean (SD)] & $10.55(8.46)$ & $5.54(5.68)$ & $\mathrm{t}=5.41 ; \mathrm{DF}=212.1$ & $0.0001^{* *}$ \\
\hline
\end{tabular}

*Chi-square test with Yates' correction

** Student's $t$ test to compare means of independent samples

*** Pearson's Chi-square test

${ }^{+}$Highest socioeconomic class according to the Economic Classification Criterion - Brazil, 2006

in relation to the healthy individuals.

Patients were found to have worse QOL scores in all domains except spirituality.

After the use of a regression model, BDI scores presented statistically significant negative correlations with all the WHOQOL-100 domains: physical $\left(r^{2}=0.33\right.$; beta $\left.=-0.39 ; \mathrm{p}<0.0001\right)$, psychological, $\left(r^{2}=0.39\right.$; beta $=-0.59 ; \mathrm{p}<0.001)$, level of independence $\left(\mathrm{r}^{2}=0.49\right.$; beta $=-0.38$; $\mathrm{p}<0.001)$, social relationships $\left(\mathrm{r}^{2}=0.25\right.$; beta $\left.=-0.46 ; \mathrm{p}<0.001\right)$, environment $\left(r^{2}=0.28\right.$; beta $\left.=-0.34 ; \mathrm{p}<0.0001\right)$, spirituality $\left(r^{2}=\right.$ 0.13 ; beta $=-0.33 ; \mathrm{p}<0.001)$, and general QOL $\left(\mathrm{r}^{2}=0.38\right.$; beta $=$ $-0.48 ; \mathrm{p}<0.05)$. The presence of a chronic health condition appeared as a significant negative factor in the physical $\left(r^{2}=0.33\right.$; beta $=-0.32$; $\mathrm{p}<0.0001)$ and level of independence $\left(\mathrm{r}^{2}=0.49\right.$; beta $=-0.49 ; \mathrm{p}<$ $0.001)$ domains, in addition to general QOL $\left(r^{2}=0.38\right.$; beta $=-0.21$; $\mathrm{p}<0.05)$. SES appeared as a significant positive factor in the social relationships $\left(\mathrm{r}^{2}=0.25\right.$; beta $\left.=0.17 ; \mathrm{p}<0.001\right)$ and environment $\left(\mathrm{r}^{2}\right.$ $=0.28$; beta $=0.29 ; \mathrm{p}<0.0001)$ domains.

\section{Discussion}

Depressive symptoms were negatively correlated with all the domains of QOL, even after adjusting for age, SES, and presence of chronic health conditions. It is important to highlight that the presence or absence of chronic health conditions appears to have a more modest association with QOL when compared to the occurrence of depressive symptoms. Our findings indicate that depressive symptoms and SES are the main elements affecting the relationship between chronic health conditions and QOL. The clinical importance of this association is clear: efforts to treat depressive symptoms should be especially reinforced in the management of clinical conditions as a means to improve QOL.

SES was positively correlated with the social relationships and environment domains of QOL. This finding also highlight the importance of socioeconomic variables for health and QOL, 
Table 2 - Comparison of WHOQOL-100 domains between groups

\begin{tabular}{|c|c|c|c|c|}
\hline WHOQOL domains & $\begin{array}{l}\text { Chronic health conditions } \\
\qquad \begin{array}{c}N=122 \\
\text { Mean (SD) }\end{array}\end{array}$ & $\begin{array}{c}\text { Healthy } \\
\mathrm{N}=119 \\
\text { Mean (SD) }\end{array}$ & $t$-test/DF & p-value* \\
\hline Psychological & $62.72(12.25)$ & $69.10(11.82)$ & $-4.11 / 239$ & 0.0001 \\
\hline Independence level & $55.76(19.43)$ & $80.24(11.25)$ & $-12.01 / 239$ & 0.0001 \\
\hline Social Relationships & $67.68(13.97)$ & $72.67(12.43)$ & $-2.93 / 239$ & 0.004 \\
\hline Environment & $56.91(10.90)$ & $63.48(10.42)$ & $-4.78 / 239$ & 0.0001 \\
\hline Spirituality & $71.33(18.93)$ & $68.96(20.49)$ & $0.93 / 239$ & 0.35 \\
\hline General QOL & $68.18(12.92)$ & $79.29(12.04)$ & $6.97 / 2391$ & 0.0001 \\
\hline
\end{tabular}

* $t$ - student test for independent samples

particularly in developing countries like Brazil, where social differences are striking. ${ }^{28,29,38,39}$ When assessing clinical patients in Brazil, clinicians and policy makers must be aware that a share of the patients' suffering may stem from poor socioeconomic conditions, and thus interventions should not be strictly focused on the relief of symptoms by the use of medication, since the data indicate that it is important to implement planned psychosocial interventions. ${ }^{17}$

An important potential limitation of our study is the recruitment method used. Although the use of the snowball technique could be a source of bias, a case-control study on drug abuse supported the idea that this technique can produce valid findings. ${ }^{40}$

There is an ongoing discussion in the literature regarding the relationship between the QOL and depression constructs. Some authors have even suggested that they are redundant constructs. ${ }^{41}$ Empirical data suggest that, although interconnected, these constructs behave differently with regard to treatment response. ${ }^{42}$ For instance, the use of the WHOQOL-100 to assess QOL after eight weeks of treatment with antidepressants showed improvement in all QOL domains, but there was only a moderate correlation between the perceived changes in QOL and the changes in depression. ${ }^{43,44}$

The confusion between constructs described above is reflected in the selection of instruments to evaluate QOL and depressive symptoms in research settings. In this study, we opted for a comprehensive scale (WHOQOL-100) to assess the distinct domains of QOL that are not necessarily linked with depression, and for a fairly specific instrument to screen for depressive symptoms (BDI). We believe that, with this, we performed an adequate separation between the results related to the different constructs.

The design of our study does not allow for the establishment of causal relationships. Based on the findings presented, we cannot state whether poorer QOL determines the occurrence of depressive symptoms or vice-versa. Only longitudinal studies can answer this question. Even so, the present investigation reinforces the importance of detecting and treating depressive symptoms in clinical patients in order to preserve their QOL, as well as to prevent health impairments associated with high levels of depressive symptoms.

\section{Conclusion}

We could conclude that the presence of depressive symptoms in this Brazilian sample had a deeper impact on QOL than did the presence of clinical conditions. Moreover, we could ascertain that socioeconomic conditions must be taken into account when studying QOL in Brazilian samples.

Table 3 - Correlations* between WHOQOL-100 domains and main variables

\begin{tabular}{|c|c|c|c|c|c|c|c|}
\hline $\begin{array}{c}\text { Dependent } \\
\text { variable }\end{array}$ & Physical & Psychological & $\begin{array}{c}\text { Independence } \\
\text { level }\end{array}$ & $\begin{array}{c}\text { Social } \\
\text { relationships }\end{array}$ & Environment & Spirituality & General QOL \\
\hline \multicolumn{8}{|l|}{ Factors } \\
\hline Age & 0.02 & 0.09 & 0.01 & -0.03 & $0.12^{* *}$ & $0.17^{* *}$ & 0.02 \\
\hline SES & 0.002 & 0.09 & 0.02 & $0.17^{* *}$ & $0.29^{\star \star *}$ & -0.13 & 0.10 \\
\hline BDI score & $-0.39^{\star \star \star}$ & $-0.59^{\star \star \star}$ & $-0.38^{\star \star *}$ & $-0.46^{\star \star \star}$ & $-0.34^{\star \star *}$ & $-0.33^{\star \star *}$ & $-0.48^{* \star *}$ \\
\hline $\begin{array}{l}\text { Chronic health } \\
\text { conditions }\end{array}$ & $-0.32^{* * *}$ & -0.04 & $-0.48^{* * *}$ & 0.05 & -0.06 & 0.08 & $-0.21^{* *}$ \\
\hline $\mathbf{R}^{2}$ & 0.33 & 0.39 & 0.49 & 0.25 & 0.28 & 0.13 & 0.38 \\
\hline $\begin{array}{l}{ }^{*} \text { Adjusted correl } \\
{ }^{* *} p<0.05 \\
{ }^{* * *} p<0.001\end{array}$ & & Linear Regı & in Models & & & & \\
\hline
\end{tabular}




\section{Disclosures}

\begin{tabular}{|c|c|c|c|c|c|c|c|}
\hline $\begin{array}{l}\text { Writing group } \\
\text { member }\end{array}$ & Employment & $\begin{array}{l}\text { Research } \\
\text { grant }^{1}\end{array}$ & $\begin{array}{c}\text { Other research grant } \\
\text { or medical continuous } \\
\text { education }^{2}\end{array}$ & $\begin{array}{l}\text { Speaker's } \\
\text { honoraria }\end{array}$ & $\begin{array}{l}\text { Ownership } \\
\text { interest }\end{array}$ & $\begin{array}{l}\text { Consultant/ } \\
\text { Advisory } \\
\text { board }\end{array}$ & Other $^{3}$ \\
\hline Neusa Sica da Rocha & UFRGS & $\begin{array}{c}\text { FIPE/HCPA* } \\
\text { CNPq }^{* *}\end{array}$ & - & - & - & - & - \\
\hline Marcelo P. Fleck & UFRGS & FIPE/HCPA* & - & - & - & - & - \\
\hline
\end{tabular}

References

1. Carney RM, Rich MW, Tevelde A, Saini J, Clark K, Jaffe AS. Major depressive disorder in coronary artery disease. Am J Cardiol. 1987;60(16):1273-5.

2. Haskett RF. Diagnostic categorization of psychiatric disturbance in Cushing's syndrome. Am J Psychiatry. 1985;142(8):911-6.

3. Mendez MF, Cummings JL, Benson DF. Depression in epilepsy. Significance and phenomenology. Arch Neurol. 1986;43(8):766-70.

4. Egede LE. Major depression in individuals with chronic medical disorders: prevalence, correlates and association with health resource utilization, lost productivity and functional disability. Gen Hosp Psychiatr. 2007;29(5):409-16.

5. Cassen NH. Depressed patients. Handbook of general hospital psychiatry. Boston: Mobsy; 1997. p.35-68.

6. Bruce ML, Seeman TE, Merrill SS, Blazer DG. The impact of depressive symptomatology on physical disability: MacArthur Studies of Successful Aging. Am J Public Health. 1994;84(11):1796-9.

7. Fleck MP, Lima AF, Louzada S, Schestasky G, Henriques A, Borges VR, Carney S. Association of depressive symptoms and social functioning in primary care service, Brazil. Rev Saude Publica. 2002;36(4):431-8.

8. Oslin DW, Streim J, Katz IR, Edell WS, TenHave T. Change in disability follows inpatient treatment for late life depression. J Am Geriatr Soc. 2000;48(4):357-62.

9. Stein MB, Cox BJ, Afifi TO, Belik SL, Sareen J. Does co-morbid depressive illness magnify the impact of chronic physical illness? A population-based perspective. Psychol Med. 2006;36(5):587-96.

10. Blumenthal MD, Dielman TE. Depressive symptomatology and role function in a general population. Arch Gen Psychiatry. 1975;32(8):985-91.

11. Broadhead WE, Blazer DG, George LK, Tse CK. Depression, disability days, and days lost from work in a prospective epidemiologic survey. JAMA. 1990;264(19):2524-8.

12. Johnson J, Weissman MM, Klerman GL. Service utilization and social morbidity associated with depressive symptoms in the community. JAMA. 1992;267(11):1478-83

13. Klerman GL. Depressive disorders. Further evidence for increased medical morbidity and impairment of social functioning. Arch Gen Psychiatry. 1989;46(9):856-8.

14. Wells KB, Burnam MA, Rogers W, Hays R, Camp P. The course of depression in adult outpatients. Results from the Medical Outcomes Study. Arch Gen Psychiatry. 1992;49(10):788-94.

15. Wells KB, Stewart A, Hays RD, Burnam MA, Rogers W, Daniels M, Berry S, Greenfield S, Ware J. The functioning and well-being of depressed patients. Results from the Medical Outcomes Study. JAMA. 1989;262(7):914-9.

16. Furlanetto LM, von Ammon Cavanaugh S, Bueno JR, Creech SD, Powell LH. Association between depressive symptoms and mortality in medical inpatients. Psychosomatics. 2000;41(5):426-32.

17. Prince M, Patel V, Saxena S, Maj M, Maselko J, Phillips MR, Rahman A. No health without mental health. Lancet. 2007;370(9590):859-77.

18. Diefenthaeler EC, Wagner MB, Poli-de-Figueiredo CE, Zimmermann PR, Saitovitch D. Is depression a risk factor for mortality in chronic hemodialysis patients? Rev Bras Psiquiatr. 2008;30(2):99-103.
19. Patrick DL, Kinne S, Engelberg RA, Pearlman RA. Functional status and perceived quality of life in adults with and without chronic conditions. J Clin Epidemiol. 2000;53(8):779-85.

20. Pyne JM, Patterson TL, Kaplan RM, Gillin JC, Koch WL, Grant I. Assessment of the quality of life of patients with major depression. Psychiatr Serv. 1997;48(2):224-30.

21. Dugan E, Cohen SJ, Bland DR, Preisser JS, Davis CC, Suggs PK, McGann P. The association of depressive symptoms and urinary incontinence among older adults. J Am Geriatr Soc. 2000;48(4):413-6.

22. Felker B, Katon W, Hedrick SC, Rasmussen J, McKnight K, McDonnell $\mathrm{MB}$, Fihn SD. The association between depressive symptoms and health status in patients with chronic pulmonary disease. Gen Hosp Psychiatry. 2001:23(2):56-61.

23. Steptoe A, Mohabir A, Mahon NG, McKenna WJ. Health related quality of life and psychological wellbeing in patients with dilated cardiomyopathy. Heart. 2000;83(6):645-50.

24. Unutzer J, Patrick DL, Diehr P, Simon G, Grembowski D, Katon W. Quality adjusted life years in older adults with depressive symptoms and chronic medical disorders. Int Psychogeriatr. 2000;12(1):15-33.

25. da Silva Lima AF, de Almeida Fleck MP. Subsyndromal depression: an impact on quality of life? J Affect Disord. 2007;100(1-3):163-9.

26. Almeida-Filho N, Mari Jde J, Coutinho E, Franca JF, Fernandes J, Andreol SB, Busnello ED. Brazilian multicentric study of psychiatric morbidity. Methodological features and prevalence estimates. Br J Psychiatry. 1997;171:524-9.

27. Almeida-Filho N, Lessa I, Magalhaes L, Araujo MJ, Aquino E, James SA, Kawachi I. Social inequality and depressive disorders in Bahia, Brazil: interactions of gender, ethnicity, and social class. Soc Sci Med. 2004;59(7):1339-53.

28. Szwarcwald CL, Bastos FI, Esteves MA. State of animus among Brazilians: influence of socioeconomic context? Cad Saude Publica. 2005;21 Suppl:33-42.

29. Theme-Filha MM, Szwarcwald CL, Souza-Junior PR. Socio-demographic characteristics, treatment coverage, and self-rated health of individuals who reported six chronic diseases in Brazil, 2003. Cad Saude Publica. 2005;21 Suppl:43-53.

30. Víctora CG. Metodologias qualitativas e quantitativas. In: Victora CG, Knauth DR, Hassen MNA. Pesquisa qualitativa em saúde- uma introdução ao tema. Porto Alegre: Tomo Editorial; 2000. p.33-44.

31. Lopes CS, Coutinho ES. Mental disorders as risk factors for the development of cocaine abuse/dependence: case-control study. Rev Saude Publica. 1999;33(5):477-86.

32. Fleck MP, Louzada S, Xavier M, Chachamovich E, Vieira G, Santos L, Pinzon V. [Application of the Portuguese version of the instrumen for the assessment of quality of life of the World Health Organization (WHOQOL-100)]. Rev Saude Publica. 1999;33(2):198-205.

33. The WHOQOL group. The World Health Organization Quality of Life Assessment (WHOQOL): development and general psychometric properties. Soc Sci Med. 1998;46(12):1569-85.

34. Beck AT. Beck depression inventory. Handbook of psychiatric measures. Washington: American Psychiatric Association; 2000. p. 519-23. 
35. Gorestein C. Inventário de depressão de beck- propridades psicométricas da versão em português. Escalas de avaliação clínica em psiquitria e psicofarmacologia. São Paulo: Lemos Editora; 2000. p.89-93.

36. Association of Brazilian Market. Economic classification criterion. Brazil; 2006.

37. Stewart R. Inference 1: chance, bias, and confounding: addressing confounding through statistical analysis. In: Prince M, Stewart R, Ford T, Hotopf M, editors. Practical psychiatric epidemiology. Oxford: Oxford University Press; 2005. p.233.

38. Ramos M. Impact of socioeconomic status on Brazilian elderly health. Rev Saude Publica. 2007;41(4):616-24.

39. Dressler WW, Balieiro MC, Ribeiro RP, dos Santos JE. A prospective study of cultural consonance and depressive symptoms in urban Brazil. Soc $S c i$ Med. 2007;65(10):2058-69.

40. Lopes CS, Rodrigues LC, Sichieri R. The lack of selection bias in a snowball sampled case-control study on drug abuse. Int J Epidemiol. 1996;25(6):1267-70.

41. da Rocha NS, Bushnell D, Power M, Fleck MP. Is there a measurement overlap between depressive symptoms and quality of life? Compr Psychiatry. 2009;50 (6):549-55.

42. Demyttenaere K, De Fruyt J, Huygens R. Measuring quality of life in depression. Curr Opin Psychiatry. 2000;15:89-92.

43. Skevington SM, Wright A. Changes in the quality of life of patients receiving antidepressant medication in primary care: validation of the WHOQOL-100. Br J Psychiatry. 2001;178:261-7.

44. Katsching H. Quality of life in depression. Quality of life in mental disorders. London: John Wiley and Sons; 1997. p.137-47. 